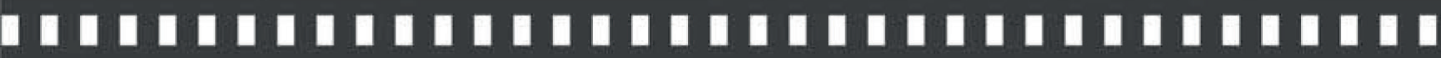

\author{
Resenha: Já tomou sua dose hoje?
}

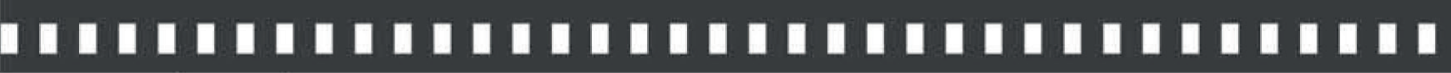

Rakelly Calliari Schacht 


\section{Já tomou sua dose hoje?}

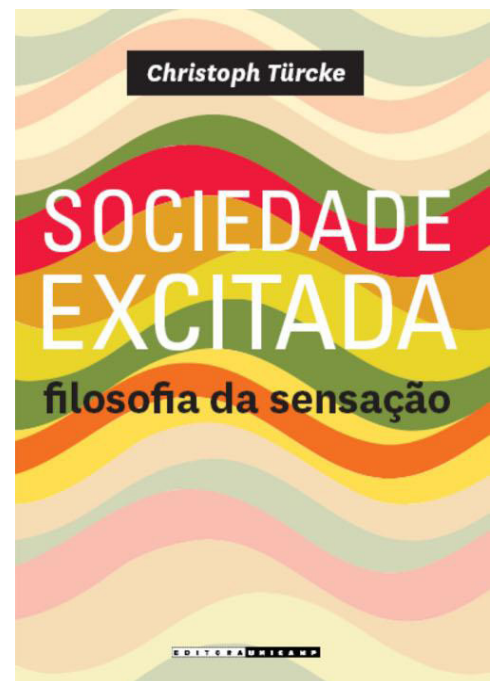

TÜRCKE, Christoph. Sociedade excitada: Filosofia da Sensação. Campinas: Unicamp, 2010.

\section{Rakelly Calliari Schacht ${ }^{1}$}

Um pesquisador que se envereda pelos estudos da imagem não demora a notar que o potencial desse ainda jovem recorte acadêmico é forjado no intenso diálogo - prático e teórico, necessário e desafiador - entre diferentes áreas do conhecimento cuja trajetória já permitiu uma sedimentação conceitual mais adensada, entre as quais destaca-se inegavelmente a Filosofia. Para além das apropriações teóricas que compõem o referencial das investigações sobre a imagem, como pode se constatar em uma passada de olhos sobre obras de autores amplamente difundidos como Roland Barthes, na fotografia, ou André Bazin, no cinema, a profusão de imagens técnicas torna-se também, ela mesma, objeto

1 Jornalista, mestre em Comunicação pela Universidade Estadual de Londrina. E-mail: rakellyc@gmail.com. 
de análise da Filosofia. É na seara mais recente dessa segunda vertente de trabalhos que se inscreve o livro "Sociedade excitada: Filosofia da sensação", do professor alemão Christoph Türcke, publicado originalmente em 2002 e editado no Brasil pela Unicamp em 2010.

Embora o livro não esteja exatamente "saindo do forno", esta resenha foi provocada pela edição da Discursos Fotográficos pelo valor das proposições de Türcke para os temas caros à revista e que, como é próprio da produção filosófica, permanecem válidas ainda que tenha por objeto um cenário em constante transformação. Curiosamente, este aparente delay corrobora justamente com a crítica tecida pela obra aqui resenhada, acerca da violência exercida pelos aparatos forjados pelo capitalismo estético sobre os sentidos humanos, explorados de maneira cada vez mais contínua e incisiva sob o pressuposto de uma concorrência que se torna imperativa em todas as relações sociais.

É nos primórdios deste período que culmina em um "mercado absoluto", na incipiente Revolução Industrial em finais do século XVIII, que o autor capta uma virada de sentido na terminologia "sensação": da designação genérica da primazia fisiológica do sentimento ou da percepção, passa a assumir conotações de "assombro, excitação, efervescência, inquietação". E quando o mercado se configura em instância central de socialização, a comunicação mercadológica - a publicidade - se autonomiza como comportamento comunicativo, exercendo influência sobre todas as esferas da vida humana. O espírito de concorrência gerado pelo mercado absoluto transforma a luta pela existência em uma luta pela percepção, elevando a um novo patamar o enunciado de George Berkeley, no século XVIII: "Esse est percepi" (Ser é ser percebido).

Ou seja, se tudo o que não está em condições de causar uma sensação tende a desaparecer sob o fluxo de informações, praticamente não sendo mais percebido, então isso quer dizer, inversamente, que o rumo vai 
na direção de que apenas o que causa uma sensação é percebido. (TÜRCKE, 2010, p. 20).

Para demonstrar a profundidade das consequências dessa transformação, Türcke recorre à produção de autores da Filosofia, Ciências Sociais, Psicanálise, Neurofisiologia, Teologia e das Teorias da Comunicação, abrindo uma nova compreensão sobre a revolução da alta tecnologia, cuja força propulsora é o choque audiovisual.

E onde estaria a faísca original da sensação absoluta contemporânea? Obviamente, na primeira técnica que permite fixar instantaneamente um recorte da realidade em suporte permanente. A fotografia, objeto de massiva difusão comercial, traz em si a industrialização da imagem e a flexibilização de tempo e espaço que se intensificaria ao longo dos anos que se seguiram. Para Türcke, o contexto ao qual Horkheimer e Adorno deram o nome de indústria cultural está previamente estabelecido no desenvolvimento da fotografia como um ramo de negócios: "o produto cultural em questão não caiu posteriormente nas garras do mercado, foi, pelo contrário, desenvolvido especialmente para ele." (TÜRCKE, 2010, p.182).

Não fossem essas características o bastante, a fotografia ainda opera como um aparelho de seleção estritamente coerente com a lógica do alvorecer industrial, quando a massa trabalhadora torna-se também objeto de seleção. A tomada fotográfica confere ao objeto captado o status de excepcionalidade, com seu olhar julgador e misericordioso, e assim passa a controlar o indivíduo, ao notá-lo e registrá-lo. Enquanto o aceita, salva-o.

Com o surgimento do cinema, seguido pela televisão e pelas telas de computador, tais imagens passam a permear igualmente o mundo do trabalho e o tempo livre, que é ocupado com distrações que exigem, justamente, concentração: o filme, o noticiário, os comerciais e - ele não cita, e nem precisaria - as redes sociais.

Essa onipresença fez com que a propaganda barulhenta 
e o caráter sensacional fossem familiarizados como condição de percepção e de vida. No contexto do capitalismo estético, em última instância a recepção do choque audiovisual se transforma em sensação absoluta indispensável à existência, pois o outro lado da moeda é também verdadeiro: "se as estações de emissão são também estações de recepção, então o esse est percipi contém também um esse est percipere: ser é perceber" (TÜRCKE, 2010, p.65). De modo que o ser humano, afinal condicionado à sensação, passa a depender fisiologicamente dessa pressão existencial do aparato sensorial. Sim, estamos todos viciados em sensação, e as agulhas estão por todo lado, em cada tela.

A origem de tamanha força é recuperada pelo autor a partir de tempos remotos. Aquilo que hoje ganha o nome de "sensação" era para os povos arcaicos a "epifania do sagrado": êxtase gerado como técnica de anestesia da dor, inclusive com o uso de imagens para externar o sentimento de pavor. Porém, assim como as substâncias psicotrópicas são desprendidas de seu significado original, assim também as imagens isoladas tornam-se objetos falsos, nos quais se busca apoio vital, mas que nunca entregarão efetivamente o prazer prometido.

"Há milênios as drogas e imagens coexistiram, a reboque do culto, como meio heterogêneo de elevação ao sagrado. Por meio do moderno procedimento técnico da isolação, que desprende substâncias ativas de seu contexto original num piscar de olhos, sendo que uma é desprendida através da destilação e outra, por meio da paralisação do instante, tanto droga quanto a imagem recebem repentinamente, uma inédita e conhecida homogeneidade. (TÜRCKE, 2010, 237).

Mas a crítica do autor não se encerra em fatalismo, pelo contrário, é chamada à (re)ação. Interessado em não apenas refletir sobre os problemas contemporâneos, mas também em contribuir com a procura de saídas para nossos labirintos ${ }^{1}$, o autor entrega um

1 Vide a publicação mais recente de Türcke lançada no Brasil, "Hiperativos! Abaixo a 
bom mapa para aqueles que ouviram seu despertador, e o ponto de partida é a educação dos sentidos. Caso contrário, continuaremos alternando embriaguez e abstinência, com aumentos da concentração audiovisual no intervalo entre um e outro. E aí? Vai mais uma dose?

Cultura do Déficit de Atenção" (Editora Paz e Terra, 2016). 